University of Windsor

Scholarship at UWindsor

Philosophy Publications

Department of Philosophy

1991

\title{
Some Sources for Hume's Account of Cause
}

Leo Groarke

University of Windsor

Graham Solomon

Follow this and additional works at: https://scholar.uwindsor.ca/philosophypub

Part of the Philosophy Commons

\section{Recommended Citation}

Groarke, Leo and Solomon, Graham. (1991). Some Sources for Hume's Account of Cause. Journal of the History of Ideas, 52 (4), 645-663.

https://scholar.uwindsor.ca/philosophypub/30

This Article is brought to you for free and open access by the Department of Philosophy at Scholarship at UWindsor. It has been accepted for inclusion in Philosophy Publications by an authorized administrator of Scholarship at UWindsor. For more information, please contact scholarship@uwindsor.ca. 


\section{UNIVERSITY OF PENNSYLVANIA}

PRESS

Some Sources for Hume's Account of Cause

Author(s): Leo Groarke and Graham Solomon

Reviewed work(s):

Source: Journal of the History of Ideas, Vol. 52, No. 4 (Oct. - Dec., 1991), pp. 645-663

Published by: University of Pennsylvania Press

Stable URL: http://www.jstor.org/stable/2709970

Accessed: $27 / 11 / 201213: 49$

Your use of the JSTOR archive indicates your acceptance of the Terms \& Conditions of Use, available at http://www.jstor.org/page/info/about/policies/terms.jsp

JSTOR is a not-for-profit service that helps scholars, researchers, and students discover, use, and build upon a wide range of content in a trusted digital archive. We use information technology and tools to increase productivity and facilitate new forms of scholarship. For more information about JSTOR, please contact support@ jstor.org. 


\section{Some Sources for Hume's Account of Cause}

Leo Groarke and Graham Solomon

The history of ideas encompasses many questions that extend beyond the interpretation of the views of particular thinkers. ${ }^{1}$ Among other things, they include questions about the relationship between the views and ideas of different times and questions about the intellectual milieu in which thinkers develop their perspectives. Hume addresses the former concerns in The Natural History of Religion and, in a more implicit way, the latter in a letter in which he tells his friend Michael Ramsay that the metaphysical parts of the Treatise will be understandable if one reads Malebranche's Recherche, Berkeley's Principles, Bayle's Dictionary, and Descartes's Meditations. ${ }^{2}$

In the present paper, we address such questions as they relate to Hume's account of cause, discussing the extent to which his views are anticipated by ancient thinkers (in particular the ancient skeptics) and the extent to which available accounts of their views may have contributed to the development of Hume's own thinking. There is, we argue, a clearer anticipation of Hume in ancient thinking than usually imagined-one which probably contributes, in at least an indirect way, to Hume's thinking on the subject.

We begin with an outline of Hume's general argument, ${ }^{3}$ leaving until

${ }^{1}$ An earlier version of this paper was presented at a November 1990 workshop on "David Hume and His Background" at the University of Western Ontario. We are especially indebted to John Wright, Tom Lennon, William Harper, and David Fate Norton for their comments; to Brian Hillyard and Mike Barfoot for information on the holdings of Edinburgh libraries; and to Roger Emerson for information about Charles Mackie. Leo Groarke would like to thank the Calgary Institute for the Humanities for a fellowship supporting the work on the present paper.

${ }^{2}$ See Richard Popkin, "So, Hume did read Berkeley," Journal of Philosophy, 61 (1954) (the letter is dated 31 August, 1737).

${ }^{3}$ A very detailed account of Hume's argument, like the one presented in J. L. Mackie's The Cement of the Universe (Oxford, 1974), esp. p.10, is unnecessary and problematic, requiring as it does a great deal of speculation about fine points of argument which are not addressed by Hume. In elaborating our account we refer to $A$ Treatise of Human Nature (2nd ed.; Oxford, 1978) as Tr. and to the Enquiry Concerning Human Understanding, ed. E. Steinberg (Indianapolis, 1977) as Enquiry.

Copyright 1991 by Journal of THE History of IDEAS, INC. 
later differences that might be thought to separate Hume and earlier thinkers (viz., his appeal to the notion of power and his discussion of probability). For the moment, the important point is that the crux of Hume's critique of cause is his claim that the grounds of our belief in cause and effect-the constant conjunction of particular kinds of eventscannot, via reason, justify a belief in causes and effects (though Hume clearly thinks that there is a more practical sense in which such a belief is justified).

We remember to have had frequent instances of the existence of one species of objects; and also remember, that the individuals of another species of objects have always attended them, and have existed in a regular order of contiguity and succession with regard to them. Thus we remember to have seen that species of object we call flame, and to have felt that species of sensation we call heat. We likewise call to mind their constant conjunction in all past instances. Without any farther ceremony, we call the one cause and the other effect, and infer the existence of the one from that of the other. $(T r, 87)$

Yet reason cannot justify the conclusion that there are causal laws. There is nothing contradictory about the supposition that nature will not proceed uniformly and we can easily imagine that particular causes are not followed by their regular effects.

There is no object, which implies the existence of any other if we consider these objects in themselves, and never look beyond the ideas which we form of them. Such an inference wou'd amount to knowledge, and wou'd imply the absolute contradiction and impossibility of conceiving any thing different. But as all distinct ideas are separable, 'tis evident there can be no impossibility of that kind. (Tr, 86-87, cf. 139)

Nor can probability establish "that instances, of which we have no experience, must resemble those, of which we have had experience, and that the course of nature continues always uniformly the same" ( $T r$, 88-89); for it is founded on the question-begging principle that there "is a resemblance betwixt those objects, of which we have had experience, and those, of which we have had none" $(T r, 90)$.

It follows that we cannot justify our belief in cause:

Thus not only our reason fails us in the discovery of the ultimate connection of cause and effects, but even after experience has inform'd us of their constant conjunction, 'tis impossible for us to satisfy ourselves by our reason, why we shou'd extend that experience beyond those particular instances, which have fallen under our observation. We suppose, but are never able to prove, that there must be a resemblance betwixt those objects, of which we have had experience, and those which lie beyond the reach of our discovery. $(T r, 91-92)$

In the end, it is habit and custom, not reason, that are the bases of all our causal inferences. This does not mean, however, that we should give up 
our belief in causes and effects. Rather, we need only recognize that it is the constant association of particular objects that makes the mind anticipate conjunctions of events and it is this psychological process, not any rational justification, that explains our faith in causal reasoning (cf. $T r, 167-69$ ).

Given the length of Hume's discussion there are, of course, many other aspects of his analysis (some of them controversial). For our purposes, it is enough to note the following four ideas that are central to it:

1. the claim that the basis of our belief in cause and effect is the constant conjunction of the objects we designate cause and effect;

2 . the claim that we cannot demonstrate the necessity of causal relationships because we can without contradiction imagine that causes are not always followed by their claimed effects;

3. the claim that it begs the question to attempt to prove the probability of causal connections (for probability assumes that unobserved instances of particular events will be conjoined with the same events as observed ones); and

4. the suggestion that we should, for practical reasons, accept a day to day belief in cause even though it cannot be justified by reason.

It is these four ideas that we shall investigate in the works of earlier thinkers, arguing, in particular, that they are found in ancient skepticism.

If one judges by the lack of references to earlier thinkers in most discussions of Hume's account of cause, one might expect few possible sources for Hume's thinking and, in consequence, many difficulties when one tries to prove an ancient source. In some ways the situation is the reverse. For though it is difficult to prove an ancient source of Hume's argument, this is in part because there are too many, not too few, possibilities. It is also difficult to decide on the likelihood of a particular source of Hume's arguments just because the psychological processes that precipitate an argument are inherently indefinite and unpredictable. It is difficult to know how Hume might have interpreted particular ancient thinkers. In the case of Hume's critique of cause, we can illustrate the questions that this raises by turning first to Lucian and his relationship to Hume.

It is difficult to establish the extent of Hume's acquaintance with Lucian's works before he wrote the Treatise, though we know that he studied under William Scot, Professor of Greek at Edinburgh, and that he thought very highly of Lucian's work later in his life. He refers to Lucian nine times in his moral, political, and literary essays, often in the most laudatory way. When he argues that ancient attitudes to women did not allow ancient writers to leave us "one piece of pleasantry that is excellent," Hume qualifies his judgment, noting that "one may except the Banquet of Xenophon, and the Dialogues of Lucian."4 In a letter to David

\footnotetext{
4 "The Rise of Arts and Science," David Hume: Essays Moral, Political, and Literary, ed. Eugene Miller (Indianapolis, 1987), 134.
} 
Hume the Younger, he recommends a course of summer reading that includes Lucian ${ }^{5}$ and Abbé Morellet begins a letter to Hume with the remark that "As Lucian is your favourite author...." Finally, we note that it is Lucian's Dialogues of the Dead Hume turns to in preparing for death. $^{7}$

Given Hume's respect for Lucian, it is interesting to note that the latter's dialogue, "Zeus Rants" contains remarks which anticipate some of the central notions in Hume's critique of cause-notions that can in principle be derived from Epicurean thought. They occur in a passage in which the Epicurean Damis ("that sly rogue") rejects the Stoic Timocles' appeal to the argument from design as a basis for a belief in the providence of the gods. Timocles answers by explaining how he has come to believe that the gods exercise providence:

In the first place the order of nature convinced me, the sun always going the same road and the moon likewise and the seasons changing and plants growing and living creatures being born, and these latter so cleverly devised that they can support life and move and think and walk and build houses and cobble shoesand all the rest of it; these seem to me to be works of providence. ${ }^{8}$

Damis replies that it begs the question to assume that the order we see in the world must be a reflection of divine providence.

While I myself would say the recurrent phenomena are as you describe them, I need not, however, at once admit a conviction that they recur by some sort of providence. It's possible that they began at random and now take place with uniformity and regularity. But you call [this] necessity "order" and then, forsooth, get angry if anyone does not follow you when you catalogue and extol the characteristics of these phenomena and think it a proof that each of them is ordered by providence. ${ }^{9}$

Though there seems no way to be sure that these comments influenced Hume, Damis clearly anticipates him when he suggests that events that occur with a regular and uniform pattern of behavior (i.e., events that are constantly conjoined) may have come about at random and may not be, therefore, necessarily conjoined. Regularity does not, in short, guarantee necessary connection.

In making such claims, Damis invokes a standard tenet of Epicurean

${ }^{5}$ Cited from David Fate Norton and Mary J. Norton, "New Light on the Hume Library," an unpublished paper presented to the Bibliographical Societies of Edinburgh and Oxford.

${ }^{6}$ John Young Thomson Grieg (ed.), Letters of David Hume (2 vols.; Oxford, 1932), II, 158 , n. 1.

${ }^{7}$ See Ernest C. Mossner, The Life of David Hume (2nd ed.; Oxford, 1980), 600-601.

8 "Zeus Rants," The Works of Lucian, tr. A. M. Harmon (Cambridge, Mass., 1960), II, 38.

${ }^{9}$ Ibid., 39. 
theory, maintaining that the present order of things one finds in the world is not necessary (though it is regular) and is the result of chance interactions of the atoms (cf. Lucretius, De Rerum Natura, 1.1024-35; Hume's discussion of such possibilities in the Dialogues Concerning Natural Religion, Part 8; and the seventeenth-century discussion of Epicureanism in Thomas Stanley's History of Philosophy). ${ }^{10}$ More generally, the Epicureans claim that it is the random (in the sense of unpredictable and undetermined) swerve of atoms that produces the world we know. Such views obviously raise questions about the extent to which our belief in cause and effect reflects necessary connections in the world and may in this way provoke the critique of necessary connection that one finds in Hume. The Epicurean principles defended in Lucian show that we can imagine (as the Epicureans do) that the present order of nature is not necessary. Hume himself scathingly rejects Epicurean principles, ${ }^{11}$ but this itself shows that he knew and considered them. Ultimately, he must find the Epicurean claim that the present order of events is not necessary too radical, preferring the weaker claim that it cannot be known to be necessary (and perhaps accepting a belief in necessary connection nonetheless). ${ }^{12}$ But this does not mean that Epicurean ideas did not motivate (or at least contribute) to the account of cause that Hume propounds.

Another possible antecedent of Hume's critique of cause is, as Ken Dorter has suggested, ${ }^{13}$ the myth of the cave in Plato's Republic (Bk. VII, 5156). Here it is suggested that the cave's prisoners are mistaken when they interpret the shadows on the wall in front of them as the cause of sounds they hear. Their interpretation of events in this way is the result of the conjunction of the shadows and the sounds and this implies that an observed conjunction of events provides no proof of a cause and effect relationship-a principle that plays a central role in Hume's reasoning.

It might be thought that this reading of the myth of the cave is an unnatural one which is possible only because we are already familiar with Hume's account of cause. One should note, however, that Plato's doubts about our ordinary view of cause and effect are a clear and obvious consequence of his rejection of the reality of the ordinary world in favor of a world of forms. This being said, it must be granted that it seems unlikely that Plato played a substantive role in the development of Hume's

${ }^{10}$ See Thomas Stanley, A History of Philosophy, 1687 (New York, 1978), 874 (Ch. II) \& 875 (Ch. V).

${ }^{11}$ In Part VIII of Hume's Dialogues, Philo asks "what if I should revive the old Epicurean hypothesis?" It is, he remarks, "commonly, and I believe, justly, esteemed the most absurd system, that has yet been proposed." However, "with a few alterations, it might . . . be brought to bear a faint appearance of probability. Instead of supposing matter infinite, as Epicureans did, let us suppose it finite...."

${ }^{12}$ For a recent account see Galen Strawson, The Secret Connexion: Causation, Realism, and David Hume (Oxford, 1989).

${ }^{13}$ Personal communication. 
thinking. His letters contain scattered references to Plato and he refers to the Republic twice in his Enquiry Concerning the Principles of Morals and twice in his moral, political, and literary essays, but he takes a very dim view of Plato's outlook, comparing "the visionary systems or ravings of Plato" to "the solid sense of Plutarch." 14

Though they anticipate some elements of Hume's account of cause, the anticipations of Hume we find in Lucian and Plato do not encompass detailed analogues of the four points we noted in our account of his discussion. In contrast, the analogue of Hume one finds in ancient skepticism provides a much more detailed anticipation of Hume's reasoning. It is in this regard worth noting that Epicurean and Platonic principles must contribute to the intellectual milieu that produced this aspect of ancient skepticism. Plato's myth of the cave is particularly significant given that it anticipates later skepticism, which might be summarized as the claim that we cannot know that the world really is as it appears (that we may, for all we know, be in the position of the prisoners in Plato's cave). Unlike Plato, however, the skeptics deny that we can find our way out of the cave and establish the true nature of the world, maintaining that we can only say how things appear relative to our subjective circumstances (the mode of relativity is, according to Sextus, the basic Pyrrhonean mode$P H, 1.29$ ).

The skeptics' view of cause and effect is discussed in detail in the extant works of Sextus Empiricus, which provide our most complete account of ancient skepticism (Sextus himself is a Pyrrhonean, but his arguments and discussion are also influenced by academic skepticism). In the present context they are especially relevant, for they were readily available to Hume. According to A. P. Cavendish, his "knowledge of Greek was inadequate for the purpose" of reading Sextus, but "the edition of J. A. Fabricius (Leipzig, 1718) included the Latin version of H. Stephens, which Hume was probably capable of reading." Cavendish nonetheless rejects any significant influence, remarking that "The only reference to Sextus in Hume's philosophical writings occurs at Essay on the Natural History of Religion, IV (1757). There can be no question of plagiarism. Hume's analysis is far more subtle and thorough than anything attempted by Sextus." 15

In answer to Cavendish's remarks, it should be said that Hume's analysis is a variant of Sextus's, that there is a second reference to him in Section XII of The Natural History of Religion, and that there is a third reference in Hume's essay "On the Populousness of Ancient Nations"16 a reference which refers to one of the books of Sextus (the Outlines of

14 "Of the Populousness of Ancient Nations," Essays, 377-464.

${ }^{15}$ A. P. Cavendish, David Hume (New York, 1968), 175.

${ }^{16}$ Essays, 399. 
Pyrrhonism, Book 3) that contains an analogue of Hume's critique of cause. More importantly, Cavendish overlooks the much more accessible version of Sextus available to Hume in the translation of the Outlines contained in Thomas Stanley's History of Philosophy. Stanley (1625-78) was known principally as a poet but turned to classical scholarship in 1651. The first volume of his History of Philosophy was published in 1655, and other volumes followed in 1656, 1660, and 1662. In 1661 he was elected a Charter Member of the Royal Society. Charles Mackie used the History as a sourcebook for undergraduates during Hume's time at Edinburgh, and both the University library and the library of the Advocates (which functioned as a library for polite Edinburgh) contained Stanley's work. ${ }^{17}$

Jonathan Barnes has claimed that Sextus does not anticipate Hume, but this is because Barnes has not considered all the relevant texts and because there are problems with his analysis of some of those he does discuss (see below). ${ }^{18}$ The most natural place to look for an analogue of Hume is in Sextus's presentation of Aenesidemus's eight tropes against the dogmatists' accounts of cause (their "aetiologies"). They encompass a variety of considerations that are not directly relevant to Hume's concerns, though modes one and four can be interpreted in a way that makes them analogues of Hume's reasoning.

The First [mode holds that Aetiology cannot be established], for . . . the kind of Aetiology, which is conversant in things not apparent, hath not an acknowledged proof from apparent things. ...

The Fourth, for ... taking Phaenomena's as they are, they think they comprehend things not apparent, as they are likewise; for things not apparent are perhaps effected the same way as Phaenomenas, perhaps some other peculiar way. ${ }^{19}$

The crux of these modes is the Pyrrhonean distinction between those things which appear (appearances or phainomena) and those things which actually exist. Modes one and four are thus founded on the claim that aetiologists attempt to establish what are, in reality, causes and effects on the basis of what appears to be the case. What appears to be the case (and what appear to be causes and effects) may, however, be distinct from what is actually the case (from what are actual causes and effects) and it follows that one cannot use the former as a basis for conclusions about the latter. According to Barnes, ${ }^{20}$ there is no reason to accept the skeptic's point

${ }^{17}$ Both libraries had the 1687 second edition; the University library had the first edition as well. In discussing Sextus's anticipation of Hume, we rely on Stanley's translation, which remains very readable today.

${ }^{18}$ Jonathan Barnes, "Ancient Skepticism and Causation," Myles Burnyeat (ed.), The Skeptical Tradition (Berkeley, 1983).

${ }^{19}$ Stanley, 787; Outlines of Pyrrhonism, 1.17.181-82 (in references to the Outlines outside Stanley, we list book, chapter and line numbers).

${ }^{20}$ The Skeptical Tradition, 164-66. 
without a reason for believing that appearances and the nonapparent are distinct, but from the skeptic's standpoint this is a case of misplaced onus. It is the dogmatists who claim to know causes and their claims can be justified only if they can justify the assumptions they depend on.

For our purposes the important point is that those things which appear to be causes and effects are those things which are constantly conjoined in our experience, and that modes one and four thus suggest that we cannot justify the dogmatists' assumption that things which are constantly conjoined are in reality causes and effects (i.e., necessarily conjoined). Reading Sextus in this way, the modes against the aetiologists do contain an analogue of Hume's critique of cause. Indeed, such an interpretation suggests that Sextus anticipates the positive and the negative side of Hume's account, for his rejection of the dogmatists' claims is coupled with a commitment to "acquiese in Phaenomena [i.e., appearances]" and use them as a criteria which determines "in the course of life what things are to be done, what not." ${ }^{21}$ In the realm of causes and effects this obviously implies an acceptance of apparent causes and effects. On the proposed reading, however, this implies an acceptance of the apparent tie between objects and events which are constantly conjoined-an acceptance which is an analogue of Hume's acceptance of causes and effects in day to day affairs.

That this is the correct interpretation of modes one and four of the Pyrrhoneans' tropes against cause is suggested by Sextus's remarks in Book Two of the Outlines, which contain a more explicit version of such reasoning in the Pyrrhonean critique of signs-a critique which shows that Sextus considers apparent causes and effects to be objects which are constantly conjoined. The principle problem with Barnes's account is his failure to note that Sextus treats causes and effects as signs of one another, a failure which allows him to overlook the critique of cause which is implied by Sextus's account of signs. The basis of this account is an account of (following Stanley) "hypomnestick" (or "admonitive") and "endictick" (or "indicative") signs.

A Hypomnestick sign, they call that which being observed to be together with a significate, evident, as soon as ever the sign evidently incurreth to our sense, tho' the significate appear not, yet it causeth us to remember that which was concomitant to it, tho' at present not evident, as smoke and fire. ${ }^{22}$

A hypomnestick or (following Bury) ${ }^{23}$ "suggestive" sign (literally, a sign which reminds us) is, in other words, one which we have observed together with its significate (what it is a sign of) to such an extent that its appearance

${ }^{21}$ Stanley, 777; Outlines, 1.11.21.

${ }^{22}$ Stanley, 800; Outlines, 2.10.100.

${ }^{23}$ Sextus Empiricus, tr. R. G. Bury (Cambridge, 1933-49). 
immediately reminds us of the significate. The constant association of smoke and fire leads us, for example, to take smoke as a hypomnestick sign, in this case an effect, of fire. Sextus applies the same account "to the scar which follows the wound, and to the puncture of the heart that precedes death; for on seeing the scar we recall the wound that preceded it, and on viewing the puncture of the heart we foretell the immanence of death" $(A M, 8.151-53)$. From Hume's point of view, those things we ordinarily call causes and effects are suggestive (i.e., hypomnestick) signs, for their constant conjunction makes us associate them with each other and it is this-not a necessary connection-which explains why we treat them as causes and effects.

The positive side of Hume's account of cause is his suggestion that we should believe in causes and effects even though we cannot build a philosophical foundation for the claims that this implies. He himself contrasts such an outlook with the tenets of Pyrrhonism, remarking that "All discourse, all action would immediately cease; and men remain in total lethargy, till the necessities of nature, unsatisfied, put an end to their miserable existence" if Pyrrhonism were to "universally and steadily" prevail (Enquiry, 128). In fact, the Pyrrhoneans adopt a position which is strictly analogous to Hume's, explicitly restricting their critique of signs to endictick signs, suggesting that we rely on hypomnestick signs in everyday life. As Sextus writes:

Of these two kinds of signs [the hypomnestick and the endictick], we oppose not both, but onely the Endictick, as seeming to be forged by the Dogmatists; the Hypomnestick [the suggestive] is creditable in the course of life; for whosoever sees smoke, knows that Fire is signified, and seeing a scar saith, it had been a wound. So as we not onely not contradict the common course of life, but maintain it, assenting inopinionatively [i.e., undogmatically] to that in it which is creditable, but opposing what is particularly forged by the Dogmatists. ${ }^{24}$

In keeping with his general claim that the Pyrrhoneans accept appearances (and only reject claims about the world beyond them), Sextus thus suggests that the Pyrrhoneans accept things which are constantly conjoined as apparent signs and apparent causes and effects, anticipating Hume's acceptance of them in day to day affairs. ${ }^{25}$

The negative side of Hume's critique of cause which we found in the modes against aetiology finds an analogue in the Pyrrhonean rejection of endictick signs. Stanley's translation of this aspect of Sextus is sometimes problematic, but it still provides a basis for Hume's critique. In introduc-

${ }^{24}$ Stanley, 800; Outlines, 2.10.102.

${ }^{25}$ One might distinguish between the kinds of belief in cause and effect that are proposed by Hume and the Pyrrhoneans by delving into the details of the Pyrrhoneans "undogmatic" belief, but such matters are beyond the scope of the present paper; for an account of Pyrrhonean belief, see Leo Groarke, Greek Scepticism: Anti-Realist Trends in Ancient Thought (Kingston, Montreal, 1990), esp. 136-40 and 144-46. 
ing the Pyrrhonean critique of signs, it notes (following the first remarks on hypomnestick signs quoted above) that:

An Endictick sign, (say they) is that which is not observed together with an evident significate, but of its own nature and constitution signifieth that whereof it is a signe; thus the motions of the body are signes of the soul.

Hereupon they define [endictick] Signe thus, Signe is a demonstrative axiome, antecedent in a sound connex, detective of that which followeth. ${ }^{26}$

This last sentence needs to be explained. A definition of the terms that it contains, found on the same page in Stanley, implies that a sign is some provable thing (axiom) which is the antecedent of a true conditional (a sound connex) and thus establishes the existence of the thing referred to in the conditional's consequent. A woman's having milk is, for example, alleged to be a sign of her having conceived, for it is alleged to be the antecedent of the true conditional, "If she has milk, she has conceived."

The claim that an endictick sign indicates its significate in "its own nature and constitution" amounts to the claim that the sign always and necessarily indicates its significate. The claim that such a sign must render true the antecedent of a true conditional that has its significate as a consequence implies a necessary connection. In the case of signs that are causes and effects, this means that endictick causes and effects must be necessarily conjoined, and that the Pyrrhonean rejection of endictick signs implies the rejection of necessary connection.

Sextus's suggestion that an endictick sign "is not observed together with an evident significate" ${ }^{27}$ may seem problematic, for this might, on first reading, be taken to imply that causes and effects are not treated as endictick signs (for they are observed together with their evident significates). ${ }^{28}$ Such a reading would destroy the symmetry between hypomnestick and endictick signs, however, and any such exclusion is contradicted by the suggestion that an endictick sign is one that makes the antecedent of a true conditional true, for this obviously can be so in the case of causes and effects. Indeed, Sextus himself gives "she hath milk" as an alleged example of an endictick sign of "she hath conceived" because they are said to be joined by the true conditional, "If she hath milk, she hath conceived." The suggestion that an endictick sign is not observed with an evident significate can, therefore, be best understood as the claim that it is not understood as a sign merely because it is constantly associated with its significate (because it is psychologically associated, as in the case of hypomnestick signs), but because it is in some stronger sense tied to its significate.

${ }^{26}$ Sextus in Stanley, 800; Outlines, 2.10.101.

${ }^{27}$ Cf. Bury: "is not clearly associated with. ..."

${ }^{28} \mathrm{His}$ example (of bodily motions as signs of the soul) might be taken as a case where signs are not observed with their significates, for mental states are not directly observable. 
In the very act of rejecting endictick signs in favor of hypomnestick signs, Sextus's critique anticipates Hume's claim that our belief in causes and effects must be founded on observed conjunctions of events which cannot establish their necessary connection. The Pyrrhonean suggestion that we should accept (and rely on) hypomnestick signs anticipates Hume's suggestion that we accept our day to day belief in cause without a philosophical foundation. It might, however, still be asked whether the Pyrrhoneans give the same grounds for rejecting the claim that constant conjunction implies necessary connection-i.e., the untenability of a defense of this implication in terms of logical necessity or probability (points 2 and 3 in our summary of Hume's reasoning). Leaving till later Hume's claims about the impossibility of defending this inference on the basis of probability, we may note that the Pyrrhoneans provide a clear analogue of Hume's suggestion that causal necessity cannot be reduced to logical necessity.

This aspect of Sextus's critique of endictick signs depends on the notion of a "relative," a concept the Pyrrhoneans use to refer to things which cannot be separately conceived. Among the examples Sextus uses to illustrate his various discussions of relatives are the concepts whiter and blacker, sweet and bitter, left and right, and whole and part (see $A M$, $8.154,161-62,9.340$ ). In general it may be said that $\mathrm{X}$ and $\mathrm{Y}$ are relatives if and only if any claim about $\mathrm{X}$ logically entails a claim about $\mathrm{Y}$ (if something is sweet it is not bitter, if it is a whole, its parts are subsumed by it, and so on). Signs which are necessarily tied to their significates (endictick signs) must be relative to their significates, for it must be impossible to imagine such signs occurring without their significates. It is only this that allows one to deduce the existence of the latter from the former (cf. $A M, 9.340$ ). The problem is that this implies that such signs and their significates are not logically distinct and cannot, therefore, function as signs and significates.

... if it [the sign] be relative to the significate, it must necessarily be comprehended together with the significate, as right with left, upwards with downwards and the like: But if it be detective of the significate, it is necessary that it be comprehended before it, that, being first known, it may bring to us the notion of the thing which is known by it... Therefore it is impossible to understand any thing which is not only relative to, but detective also of, that to which it is relative: But a [endictick] sign, say they, is both relative to, and detective of the significate, therefore it is impossible to understand the sign. ${ }^{29}$

It is important to see that the temporal considerations this argument invokes are not essential to it. Thus the crux of the Pyrrhoneans' reasoning is the claim that signs and significates (e.g., smoke and fire) must be distinct entities and that this cannot be the case if they are necessarily

${ }^{29}$ Stanley, 801; Outlines, 2.11.119-20. 
(i.e., logically) conjoined. The latter implies that they cannot be temporally distinct, but this is a consequence of the more basic point that they cannot be separately conceived. As Sextus notes, "the sign is relative to the significate, and relatives are comprehended together with one another," and an endictick sign cannot, therefore, be apparent without its significate and is useless as a sign. "For as right and left incurring to us together, right is not said to be more apparent than left, or left than right; in like manner the sign and the significate being comprehended together, it cannot be said that the sign is more apparent than the significate: But if the significate be apparent, it is not a significate, as not needing any to signifie and detect it." 30

Applying this reasoning to endictick signs which are said to be causes and effects of one another, it can be said that they must be relatives and thus logically inseparable. But this implies that they are not logically distinct objects and not, therefore, genuine causes and effects. As Hume puts it at one point, "There is nothing in any object, consider'd in itself, which can afford us a reason for drawing a conclusion beyond it" $(T r$, 139).

Hume's argument against cause employs the same logical considerations, though it goes the other way around, assuming that causes and effects are distinct and concluding that they are not necessarily conjoined. As he puts it, "There is no object, which implies the existence of any other [distinct object] if we consider these objects in themselves, and never look beyond the ideas which we form of them. Such an inference wou'd amount to knowledge, and wou'd imply the absolute contradiction and impossibility of conceiving any thing different. But as all distinct ideas are separable, 'tis evident there can be no impossibility of that kind" $(T r, 87)$.

Sextus explicitly applies the temporal version of such reasoning to causes and effects in Book III of the Outlines, in a section one of the first reviewers of the Treatise suggests as similar to Hume's argument against cause. ${ }^{31}$ According to the relevant part of Sextus's discussion (a part which Barnes does not discuss), there is no way to establish that there are any causes, for causes must precede their effects and this is impossible given that causes and effects are supposed to be relatives, i.e., necessarily conjoined and thus logically inseparable.

... a Cause ... must first exist, and be a Cause, and then produce the Effect, which is said to be the Effect thereof, The Cause already existing. But Cause

${ }^{30}$ Ibid.

${ }^{31}$ In the Bibliothèque raisonée for April-May-June 1740. The reviewer notes that Hume's discussion of cause "is pretty close to the manner in which Sextus Empiricus formerly reasoned in his Hypotyposes, Book III, Chap. III." This remark is noted in Mossner, The Life of David Hume, 129. A. P. Cavendish was puzzled by the section of Sextus referred to, but we will argue that it contains an analogue of Hume's critique. 
being relative to the Effect, it is manifest that, as Cause, it cannot exist before it. $^{32}$ (Cf. $A M, 2.168,9.234-36$ )

If we want to put the same argument in words that are closer to Hume's, we might begin with his already quoted claim that "There is nothing in any object, consider'd in itself, which can afford us a reason for drawing a conclusion beyond it" ( $T r, 139)$. This suggests that we can establish the existence of an effect from the existence of a cause only if its effect is not logically distinct. But then the one cannot occur before the other, as is required by the concept of a cause and its effect. Here again, the important point is that distinct causes and effects can be conceived without each other and need not, therefore, be necessarily conjoined.

Of the four aspects of Hume's account of cause we noted at the outset, the only one we have not yet found in Sextus is the suggestion that a belief in cause and effect cannot be defended by an appeal to probability. Given no clear distinction between objective and subjective probability (Carneades' pithanon is better understood as a notion of plausibility), ${ }^{33}$ the Pyrrhoneans do not discuss it in a direct way, but their critique of inductive inference encompasses the crux of Hume's analysis in this regard. Indeed, there is a sense in which it is more comprehensive than Hume's reasoning, for it rejects all inductive inferences (and is not restricted to an attack on causal claims), questioning the assumption that the regularities we have observed in nature will continue in the future. As Sextus puts it, an induction cannot be known to be correct as long as we have not observed all instances of the phenomena in question, "it being possible, that some of the omitted Particulars may be found contrary to the Universal Proposition" 34 (cf. Hume's complaint that probability "is founded on the presumption of a resemblance betwixt those objects, of which we have had experience, and those, of which we have had none," $\operatorname{Tr}, 90)$. As Sextus notes elsewhere, such reasoning shows that generalizations like "Every man is a living creature" and "No man is four footed" cannot be justified. ${ }^{35}$ Exactly the same reasoning is applicable to causal inductions (for they are also based on the question-begging assumption that future observations will confirm past ones) and it would, therefore, be a mistake to think

${ }^{32}$ Stanley, 815; Outlines, 3.5.26-28. Cf. the remarks that "Relatives, as Relatives, coexist, and are understood together; but ... it is necessary, that a Cause first be a Cause before it produce the Effect" (ibid.) and that "if we cannot understand a Cause (forasmuch as it is relative,) before its Effect; and, to understand it as Cause of the Effect, it be necessary to understand it, as being before the Effect ... then it is impossible to understand that there is Cause" (ibid.).

${ }^{33}$ It is a measure of the force of the impression we experience and not as clearly tied to the enumeration of particular cases as the notion of probability Hume adopts. On this point, see Myles Burnyeat, "Carneades Was No Probabilist," forthcoming.

${ }^{34}$ Stanley, 807; Outlines, 2.15.204.

${ }^{35}$ Ibid. 
that Sextus's discussion contains no antecedent of Hume's arguments against the probability of inductive inferences.

It should by now be clear that Sextus's Outlines of Pyrrhonism contains an extensive analogue of Hume's critique of cause. The question whether this analogue influenced Hume remains. In favor of direct influence, one might note that Stanley's translation made Sextus very readily accessible and that it would at least be odd to find that someone preoccupied with skepticism as a problem would not consult the most accessible text that represents the views of real skeptics. In answer to such suggestions, one might point to modern and contemporary epistemology, which is equally caught up with the problem of skepticism, but for the most part ignores the details of the ancient skeptics' views (even when it makes reference to the ancient schools). ${ }^{36}$ Given such considerations and Hume's own caricature of the Pyrrhonean position, ${ }^{37}$ it seems unlikely that Hume was familiar with the details of Sextus's Outlines when he composed the Treatise.

In contrast, it is much more difficult to dismiss the possibility of indirect influence on Hume's thinking. Given Stanley's translation, the appropriate sections of Sextus were available, not just to Hume, but to all of his contemporaries. Most notably perhaps, Hume's teachers did know Stanley. That the relevant sections of Sextus were disseminated to at least some extent is shown by the reference to Sextus in the review of the Treatise cited above (assuming Hume saw the review, it is difficult to believe that he would not have looked it up).

Given that we can never know what passed in conversation between Hume, his fellow students, his professors and acquaintances, an exact account of the development of his ideas on cause seems impossible, though it seems certain that ancient philosophy provided a context for much of this discussion. Indeed, Hume's reading of Bayle establishes this in a very general way. Sextus's anticipation of Hume's arguments against cause and the more general anticipations one finds in Lucian and even Plato (and in Sextus's very general tropes, from which one can derive the critique of cause), are not, therefore, compatible with the usual assumption that ancient discussion had no effect on Hume's thoughts about the problems of causes and effects. To reinforce this conclusion, we finish our discussion with an account of other thinkers who influenced Hume's account of cause.

Given the possibility that Sextus influenced Hume's account of cause,

${ }^{36}$ See Groarke, Greek Scepticism.

${ }^{37}$ On this point, cf. David Fate Norton's remark that "It is difficult to reconcile ... Pyrrhonism with Hume's views on the topic" (David Hume: Common-Sense Moralist, Sceptical Metaphysician [Princeton, 1982], 266). 
it is natural to ask how such influence fits with other accounts of the genesis of Hume's ideas in this regard. Malebranche is the most important figure in this regard, for Charles McCracken has shown that "There can be no question that Hume, when composing the account of causality in the Treatise, had Malebranche's treatment of that topic in his thoughts." 38 Indeed, the parallel passages McCracken notes convincingly establish that "Hume not only kept the Search [The Search for Truth] in mind as he wrote on causality, but that he even had it open for consultation while writing."39

Two things should be said about the implications of such considerations in the present context. Firstly, and most obviously, it must be said that a variety of influences probably manifest themselves in Hume's views, and that Malebranche's influence does not, therefore, exclude the possibility of other influences. Secondly, it should be noted that Malebranche himself is to some extent a vehicle for ancient skeptical doubts, and his influence on Hume thus supports rather than diminishes the probability of the general claim that Hume's views are tied to ancient skepticism.

Ancient doubts about causation were available to Malebranche in the same way they were available to Hume-via Stanley's translation of Sextus-but his preoccupation with occasionalism (the doctrine that God is the only efficient cause) suggests a more circuitous route from ancient skepticism. To understand this route, we must first turn to medieval anticipations of Hume's views.

Though there is no reason to think that the arguments they employ are exclusively theirs, two figures mentioned as medieval precursors of Hume on cause are the fourteenth-century French philosopher, Nicholas of Autrecourt (dubbed "the medieval Hume)" 40 and the eleventh-century Islamic thinker, al-Ghazali. For our purposes, the apparent lack of any plausible link between Nicholas and Hume makes Nicholas interesting only because his views may be yet another manifestation of ancient skeptical concerns. ${ }^{41}$

${ }^{38}$ Charles J. McCracken, Malebranche and British Philosophy (Oxford, 1983), 257.

${ }^{39}$ Ibid., 258.

${ }^{40} \mathrm{Cf}$. the introduction to the selections from Nicholas in A. Hyman and J. J. Walsh (eds.), Philosophy in the Middle Ages (Indianapolis, 1973), 654.

${ }^{41}$ In Nicholas of Autrecourt (Princeton, 1948), Julius Weinberg questions Nicholas's knowledge of earlier skeptics, but there are many references that suggest that he was familiar with their work. At one point, he refers to the academic skeptics, suggesting that Bernard's position entails "the absurdities of the Academics." His familiarity with Pyrrhonean skepticism seems reflected in his use of Rome as an example of what is not immediately evident (cf. his Universal Treatise 228 and $P H 2.98 ; A M$ 8.145); in his extended discussion of the standard Pyrrhonean antithesis between the tastes of things which appear sweet to the healthy and bitter to the sick (ibid., 228 and passim.); in his appeal to appearances as a basis for belief; and in the general structure of his basic arguments for skepticism. Above and beyond this circumstantial evidence, there may be an explicit reference to the Pyrrhoneans in Nicholas's second letter to Bernard, where he argues that 
Ghazali's views are more important because they have been linked to Malebranche's occasionalism. His critique of cause is included in The Incoherence of the Philosophers (the Tahafut al Falasifa), which attacks Aristotle and his Islamic followers on twenty points which contradict the tenets of orthodox Islam. He finds a belief in strict natural necessity unacceptable because it makes God an amorphous first cause, remote from day to day reality and unable to intervene in the natural order of events. In order to reestablish God's omnipotence and the possibility of miracles, Ghazali defends occasionalism, the view that God is the immediate cause of all events. Unlike Sextus, Ghazali therefore introduces the notion of God into his analysis. Theological considerations thus motivate his arguments though they do not play a crucial role in logically establishing his conclusions (the notion that God is the basic efficient cause is already found in Anaxagoras and in Stoicism, and is mentioned in Sextus at $A M, 9.6$; elsewhere Sextus remarks that the majority have declared that God is a most efficient Cause and therefore begins an account of efficient principles "by inquiring about God ..."- $P H, 3.2){ }^{42}$

In defending his occasionalism, Ghazali rejects natural necessity, holding that our belief that objects and events are causes and effects is based on God's decision to ". . . create them in a successive order, though not because this connection is necessary in itself and cannot be disjoined. On the contrary, it is in God's power to create satiety without eating and decapitation without death, and so on with respect to all connections." ${ }^{43}$ Like Hume, Nicholas, and the Pyrrhoneans, Ghazali bases his critique of

the external world is not known intuitively, for if it were, "rustics" (rustici) would know that it exists. Weinberg (39) takes this literally, as a reference to peasants, but they do not, in any straightforward way, deny the existence of the external world. Rather than peasants, it seems that it is Pyrrhoneans that Nicholas has in mind, using a Latin equivalent of a term we find in Galen, when he calls the more radical skeptics "rustic Pyrrhoneans" (agroikopyrroneious, 8.711.1-3). Obviously, they clearly deny our knowledge of external objects and Nicholas can, therefore, legitimately invoke them to show that it cannot be assumed.

${ }^{42}$ According to Weinberg, Nicholas of Autrecourt's critique of cause is more radical than any propounded by predecessors like Ghazali because it is less dependent on God's ability to intervene in the natural order of events. It is, however, hard to see why this would make it stronger (unless one assumes, in an ad hoc way, that one can disprove the existence of God) and the claim that God can perform miracles does not play a crucial role in Pyrrhonean arguments or in al-Ghazali. In the latter case it is a conclusion, not a premise, in Ghazali's reasoning. Ghazali is motivated by religious commitments, but this is another matter and Nicholas invokes a similar appeal when (in his fifth letter) he suggests that God may be the only efficient cause. Unlike Ghazali, he does not personally endorse such a view (ibid., 259), but still holds that it is a possibility which cannot be disproven, and which entails that natural causes may not exist (or may even be impossible).

${ }^{43}$ Tahafut al Falasifa, in Averroes's Tahafut al Tahafut ("The Incoherence of the Incoherence," a response to Ghazali which includes his entire text), Simon Van Den Bergh, ed. and tr. (2 vols.; London, 1954), I, 517. 
cause on the claim that the distinctness of cause and effect shows that it is not contradictory to deny causal necessity.

According to us, the connection between what is usually believed to be a cause and what is believed to be an effect is not a necessary connection; each of two things has its own individuality and is not the other, and neither the affirmation nor the negation, neither the existence nor the non-existence of the one is logically implied in the affirmation, negation, existence and non-existence of the other. ... ${ }^{44}$

According to Ghazali, our observations of causes and effects and the habits they produce only establish their past conjunction, and not a necessary connection. In attempting to prove that contact with fire causes a piece of cotton to burn, for example, "the philosophers have no other proof than the observation of the occurrence of the burning, when there is contact with fire, but observation proves only a simultaneity, not a causation, and, in reality, there is no other cause but God." 45 This does not mean that we should give up reliance on causes and effects in ordinary affairs but only that we cannot justify it and that we should instead accept the regularity of God's actions.

Ghazali is important in the present context because he influenced Malebranche, who adopted a similar occasionalism which seems to have exerted a great influence on Hume's thinking. According to Naify, Hume "simply took over Malebranche's criticism of the traditional theories [of cause], and then turned a part of Malebranche's critical apparatus against him," arguing that God's role as cause is similarly unprovable. ${ }^{46}$ Naify's suggestion that Malebranche is indebted to Ghazali is confirmed by Lennon, who notes that Malebranche gives Suarez's discussion of the views of Averroes (and, implicitly, Ghazali) as the source of his occasionalist concerns. ${ }^{47}$

In light of our concerns, the important point is that Hume's ties, via Malebranche and Suarez, to Ghazali bind him once again to ancient skepticism, for it exerted a great influence on Ghazali and the Islamic tradition of which he is a part. ${ }^{48}$ Van Den Bergh's discussion of the debate between Ghazali and Averroes thus contains forty-four references to Sextus Empiricus, and Ghazali's discussion repeatedly employs the kinds of example one finds in ancient skeptical discussions of causation-in particular, burning, the possibility of an individual changing into another species, and the different effects the sun and fire have on different things

${ }^{44}$ Ibid.

${ }^{45}$ Ibid., 518, cf. 537.

${ }^{46}$ James Frederick Naify, Arabic and European Occasionalism (Ph.D. diss., San Diego, 1975), 181.

${ }^{47}$ Thomas Lennnon, “Veritas Filia Temporis: Hume on Time and Causation," History of Philosophy Quarterly, 2 (1985), 287.

${ }^{48}$ See Van Den Bergh's extensive notes. 
(see $A M, 9.202-3,241,247-49 ; P H, 3.18$; cf. $A M, 8.192-94$, D.L. 9.104). Medical examples like those that Ghazali uses were probably a standard part of the repertoire of the ancient empirical school of medicine, which has ties to Pyrrhonism and denies the possibility of establishing causes and effects. Such ties are confirmed by Maimonides' remark that "One must know everything the moslems, Mu'tazilites as well as Ash'arites [the latter sect being al-Ghazali's], have professed concerning these subjects, has been borrowed from the Greeks and Syrians who applied themselves to the criticism of the philosophers [i.e., the skeptics]." ${ }^{49}$ It is difficult (perhaps impossible) to determine the exact way in which ancient skeptical discussions of cause influence Ghazali, but it can safely be said that some such influence constitutes one way in which the Pyrrhonean critique of cause did indirectly influence Hume, in this case via Malebranche.

Rather than show that Sextus did not influence Hume, then, the hypothesis that his account of cause is ultimately derived from al-Ghazali's occasionalism supports an indirect connection. Yet another possibility is indirect influence through some of Hume's contemporaries who were familiar with Sextus in the Greek or Latin, or through Thomas Stanley's History. Joseph Glanvill is a case in point, though Popkin has argued that his influence on Hume's account of cause is minimal. ${ }^{50}$ Some such possibility may be indicated by Hume's use of the notion of a "relative" when he discusses the possibility of justifying a belief in power as a basis for a belief in cause, remarking that "the idea of power is relative as much as that of cause; and both have a reference to an effect, or some other event constantly conjoined with the former." ${ }^{51}$ A detailed examination of all the possibilities of indirect influence are, however, beyond the scope of the present paper.

We have been concerned to make the following main points: (1) An-

${ }^{49}$ Guide of the Perplexed, 1.71, Van den Bergh, II, 1.

${ }^{50}$ H. G. Van Leeuwen remarks that "Ferris Greenslet, in his Joseph Glanvill: $A$ Study in English Thought and Letters of the Seventeenth Century (New York, 1900), points out that Glanvill's account of the causes of human ignorance is derived in large measure from Sextus Empiricus. Glanvill may have had direct access to a copy of Sextus's writings, or may have used Thomas Stanley's The History of Philosophy (London, 1655), which contains large extracts from the skeptic's writings" (H. H. Van Leeuwen, The Problem of Certainty in English Thought, 1630-1690 [2nd ed.; The Hague, 1970] 79). Richard Popkin discusses Glanvill's skepticism about causation and his influence on Hume in "Joseph Glanvill: A Precursor to David Hume," JHI, 14 (1953), 292-303. Popkin remarks that Glanvill "indicates ... that the Humean theory of causality is latent in the Pyrrhonean point of view."

${ }^{51}$ Enquiry VII ii 77n. Cf. ft. 32, above. And we note, contra Barnes, that Hume's reference to "power" does not clearly distinguish him from the ancient skeptics (see Barnes, 178). Hume believed cause is the crucial notion and an appeal to the notion of power reduced to an appeal to the notion of cause and effect. Having the power to produce something "is synonymous to causing" (Enquiry, VIII ii 74n). 
cient skepticism does (contra Barnes) contain a clear analogue of central aspects of Hume's account of cause. (2) This aspect of ancient skepticism was readily available to Hume and his contemporaries through the seventeenth-century Stanley translation of Sextus's Outlines of Pyrrhonism. (3) Other possible seventeenth-century sources for Hume's thoughts on cause (viz., Malebranche) also suggest a link to ancient thought. The gap between ancient and early modern philosophy may not be the chasm that the rhetoric of the early moderns would have us believe.

Wilfrid Laurier University. 